\title{
ЕФЕКТИВНІСТЬ ЗАСТОСУВАННЯ ХІМІЧНИХ МУТАГЕНІВ В СЕЛЕКЦІї СӦ̈
}

С. С. Рябуха, П. В. Чернишенко, Л. Г. Сєрікова

Інститут рослинництва ім. В. Я. Юр'єва НААН України

Проаналізовано ефективність застосування хімічних мутагенів в селекції сої. Створено високопродуктивні мутантні сорти сої зернового та зернокормового напрямів використання: Харківська зернокормова, Романтика, Скеля, Величава, Подяка .

Соя, селекиія, хімічний мутагенез, сорт

Постановка проблеми. Соя - одна з найпоширеніших у світовому землеробстві культур універсального використання, якій належить провідна роль у розв'язанні глобальної білкової проблеми.

В Україні посіви сої за останнє десятиріччя стрімко зросли і в 2010 р. перевищили 1 млн. га. У 2011 р. валовий збір соєвого насіння склав 2,4 млн. т при рівні урожайності 2,04 т/га. У 2012 р. посіяно 1,324 млн. га, а до 20152017 рр. планується розширення посівних площ сої до 2,0-2,5 млн. га.

Сучасна селекції сої спрямована на підвищення урожайності, технологічності, стійкості до біо- та абіотичних чинників, оптимізацію вегетаційного періоду, покращення товарних та технологічних якостей насіння. Успіх селекційної роботи залежить від відповідного базового та експериментального матеріалу, методів і техніки роботи $[1,2,3]$.

Одним із методів селекції сої є індукований мутагенез, спрямований на штучне одержання життездатних корисних мутацій. Мутагенні чинники в селекції сої найчастіше використовують при створенні нових форм, які відрізняються від вихідних сортів за окремими ознаками: крупністю насіння, висотою рослин, формою листа, забарвленням насіння, стійкістю до збудників захворювань, тривалістю вегетаційного періоду, вмістом і якістю білка та олії в насінні $[3,4]$.

Питання застосування хімічних мутагенів для створення сортів сої вивчали ряд вітчизняних та зарубіжних дослідників. У своїх дослідженнях А. К. Лещенко встановила більшу мутабельність культурних форм, порівняно із дикорослою соєю $[3,4]$. Було виділено понад 30 груп різних за фенотипом мутантів [3]. В. Б. Снкеним виявлено, що чим більше у сорту домінантних ознак, тим він мутабільніший, а ступінь вираження кількісної ознаки у вихідних сортів значною мірою визначає амплітуду його індукованої

(C) С. С. Рябуха, П. В. Чернишенко, Л. Г. Сєрікова. 2012.

ISSN 0582-5075. Селекція і насінництво. 2012. Випуск 102. 
мінливості. С. Г. Теодорадзе показав, що у сортів гібридного походження під впливом мутагенів відбувається більше спадкових змін, ніж у сортів, створених методом добору $[3,5]$. Дослідження А. Я. Али та В. С. Али довели більшу мінливість кількісних ознак при обробці насіння мутагенами i встановили, що у подальшому під впливом природного добору у деяких випадках відбувається повернення середньої величини ознаки до початкового рівня. В. І. Січкарем встановлено найбільшу мутагенну активність для сої нітрозоетилсечовини, нітрозометилсечовини та гама-променів, а А. М. Борейко, Н. С. Шевченко, Г. Н. Беляєвою, У. А. Акіловим, Ю. П. Мякушком та ін. одержані високопродуктивні мутанти з комплексом господарськи корисних ознак. У Румунії, Угорщині та Польщі було виділені зразки з різною опушеністю стебла і бобів та стійкістю до вилягання, скоростиглі мутанти із вкороченими міжвузлями, холодостійкі форми [3].

У колишньому СРСР, Японії, Таїланді, Ямайці та інших країнах створено мутанти з підвищеним вмістом білка і його складових фракцій. Використовуючи нітрозоетилсечовину та нітрозодіетилсечовину, Ю. П. Мякушко індукував стійкі до сім'ядольного бактеріозу форми з частотою $0,2-0,7 \%$ [3].

Мета досліджень. Дослідження були спрямовані на вивчення ефективності застосування хімічних мутагенів при створенні нових сортів сої.

Матеріали та методика досліджень. Матеріалом для досліджень були сорти та селекційні зразки сої різного походження. Обробку насіння сої хімічними мутагенами проводили в Інституті фізичної хімії АН СРСР (м. Москва) та в Інституті фізіології рослин та генетики НАН України (м. Київ). Застосовували водні розчини хімічних мутагенів з концентрацією: діетилсульфат - 0,025-0,050 \%, нітрозометилсечовина- 0,012 та 0,025\%, нітрозоетилсечовина - 0,025 та $0,050 \%$. Вивчення оброблених зразків сої проводили у мутаційному розсаднику, де їх порівнювали з вихідними формами та сортами-стандартами. Площа ділянки становила $3,6 \mathrm{~m}^{2}$ та 10,0 м². Відібрані рослини з ознаками мутагенної дії висівали для подальшого вивчення в селекційному розсаднику.

Конкурсне сортовипробування перспективних зразків проводили за стандартною методикою по загальноприйнятій для Лісостепової зони України технології вирощування: норма висіву 600 тис. схожих насінин на га, ширина міжрядь 45 см, облікова площа ділянки $25 \mathrm{~m}^{2}$, повторність досліду чотириразова [6].

Результати досліджень. Застосування хімічних мутагенів та наступного багаторазового добору дозволило створити ряд нових сортів сої різних напрямів використання, з яких п'ять занесено до Державного реєстру сортів рослин, придатних до поширення в Україні (Держреєстр). Створені сорти мають різноманітні ідентифікаційні ознаки (табл. 1).

Сорт зернокормового напряму використання Харківська зернокормова створено шляхом обробки насіння сорту Харківська 80 розчином діетилсульфату в концентрації 0,025 \% 3 подальшим багаторазовим добором. 
Таблиця 1

Основні ідентифікаційні ознаки мутантних сортів сої селекції Інституту рослинництва ім. В. Я. Юр'єва НААН

\begin{tabular}{|c|c|c|c|c|c|c|}
\hline \multirow[b]{2}{*}{ Сорт } & \multicolumn{4}{|c|}{ Колір } & \multirow[b]{2}{*}{$\begin{array}{c}\text { Висота } \\
\text { рос- } \\
\text { лин, см }\end{array}$} & \multirow{2}{*}{$\begin{array}{l}\text { Maca } \\
1000 \\
\text { насі- } \\
\text { нин, Г }\end{array}$} \\
\hline & $\begin{array}{c}\text { опуше- } \\
\text { ння }\end{array}$ & квітки & насіння & $\begin{array}{c}\text { насін- } \\
\text { нєвого } \\
\text { рубчика }\end{array}$ & & \\
\hline $\begin{array}{l}\text { Харківська } \\
\text { зернокормова }\end{array}$ & рудий & $\begin{array}{c}\text { фіолето- } \\
\text { вий }\end{array}$ & $\begin{array}{l}\text { жовто- } \\
\text { зелений }\end{array}$ & чорний & $60-70$ & $150-160$ \\
\hline Романтика & $\begin{array}{l}\text { світло- } \\
\text { рудий }\end{array}$ & $\begin{array}{c}\text { фіоле- } \\
\text { тово- } \\
\text { рожевий }\end{array}$ & $\begin{array}{l}\text { світло- } \\
\text { жовтий }\end{array}$ & $\begin{array}{c}\text { темно- } \\
\text { корич- } \\
\text { невий } 3 \\
\text { вічком }\end{array}$ & $75-85$ & $150-160$ \\
\hline Скеля & $\begin{array}{l}\text { біло- } \\
\text { сірий }\end{array}$ & $\begin{array}{c}\text { світло- } \\
\text { фіолето- } \\
\text { вий } \\
\end{array}$ & жовтий & жовтий & $110-130$ & $160-170$ \\
\hline Величава & $\begin{array}{l}\text { біло- } \\
\text { сірий }\end{array}$ & білий & жовтий & жовтий & $100-110$ & $150-160$ \\
\hline Подяка & $\begin{array}{c}\text { жовто- } \\
\text { корич- } \\
\text { невий }\end{array}$ & $\begin{array}{c}\text { фіолето- } \\
\text { вий }\end{array}$ & жовтий & $\begin{array}{c}\text { темно- } \\
\text { корич- } \\
\text { невий } 3 \\
\text { вічком }\end{array}$ & $100-110$ & $110-130$ \\
\hline
\end{tabular}

Сорт відрізняється від вихідної форми за морфологічними (забарвлення рослин та насіння) та біохімічними (жирнокислотний склад олії) ознаками.

Урожайність сорту Харківська зернокормова у конкурсному сортовипробуванні у 1988-1990 pp. склала 1,95 т/га, урожайність зеленої маси 27,0 т/га, що відповідно на 0,20 та 6,0 т/га більше, ніж у сорту-стандарту Білосніжка. На Артемівській сортодільниці Донецької області при зрошенні урожайність в 1991 році досягла рівня 4,08 т/га. Сорт середньостиглий (тривалість вегетації 105-110 діб), стійкий до посухи, вилягання, обсипання насіння, збудників хвороб і шкідників. Вміст білка в насінні - 40,6 \%, олії $22,5 \%$. Олія із насіння цього сорту відрізняється високим вмістом гліцеридів пальмітинової (16,3\%), стеаринової (5,2 \%) та олеїнової (22,5 \%) кислот

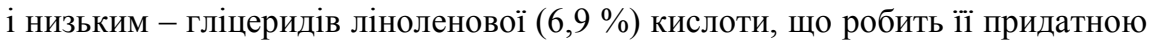
для використання у харчовій промисловості (консервній галузі та виробництві високоякісних маргаринів). Сорт Харківська зернокормова придатний для виробництва зерна, а також зелених та грубих кормів для тваринництва, як у чистих, так і у сумісних посівах. Сорт занесено до Держреєстру 3 1993 р. по зонах Полісся, Лісостепу і Степу (табл. 2).

Зерновий сорт Романтика одержано при обробці насіння сорту Білосніжка 0,012 \% розчином нітрозометилсечовини та подальшому доборі. Він відрізняється від вихідного сорту за морфологічними ознаками (опушення стебла, крупність та форма насіння, колір насіннєвого рубчика). 
Таблиця 2

Господарсько цінні ознаки мутантних сортів сої селекції Інституту рослинництва ім. В. Я. Юр'єва НААН (конкурсне сортовипробування)

\begin{tabular}{|c|c|c|c|c|c|c|}
\hline \multirow{2}{*}{ Сорт } & \multirow{2}{*}{ Роки } & \multicolumn{2}{|c|}{ Урожайність } & \multirow{2}{*}{$\begin{array}{c}\text { Трива- } \\
\text { лість } \\
\text { вегетації, } \\
\text { діб }\end{array}$} & \multicolumn{2}{|c|}{$\begin{array}{c}\text { Вміст } \\
\text { в насінні, \% }\end{array}$} \\
\hline & & т/га & $\begin{array}{c} \pm \text { до } \\
\text { стандарту }\end{array}$ & & білка & олії \\
\hline Білосніжка - стандарт & \multirow{2}{*}{$\begin{array}{l}1988- \\
1990\end{array}$} & 1,75 & - & $90-100$ & 38,5 & 22,0 \\
\hline $\begin{array}{l}\text { Харківська } \\
\text { зернокормова }\end{array}$ & & 1,95 & $+0,20$ & $105-110$ & 40,6 & 22,5 \\
\hline $\mathrm{HIP}_{05}$ & - & 0,13 & - & - & - & - \\
\hline Білосніжка - стандарт & \multirow{2}{*}{$\begin{array}{r}1992- \\
1994\end{array}$} & 1,18 & - & $90-100$ & 39,0 & 21,8 \\
\hline Романтика & & 1,49 & $+0,31$ & $90-100$ & 39,5 & 21,5 \\
\hline $\mathrm{HIP}_{05}$ & - & 0,18 & - & - & - & - \\
\hline Київська 27 - стандарт & \multirow{2}{*}{$\begin{array}{l}2000- \\
2002\end{array}$} & 1,79 & - & $112-114$ & 39,4 & 20,9 \\
\hline Скеля & & 2,26 & $+0,47$ & $110-115$ & 39,5 & 23,5 \\
\hline $\mathrm{HIP}_{05}$ & - & 0,20 & - & - & - & - \\
\hline Київська 27 - стандарт & \multirow{3}{*}{$\begin{array}{l}2002- \\
2004\end{array}$} & 2,23 & - & $112-114$ & 38,9 & 20,8 \\
\hline Величава & & 2,68 & $+0,45$ & $110-115$ & 40,5 & 22,5 \\
\hline $\mathrm{HIP}_{05}$ & & 0,20 & - & - & - & - \\
\hline Київська 27 - стандарт & \multirow{2}{*}{$\begin{array}{l}2006- \\
2008\end{array}$} & 1,80 & - & $112-114$ & 39,1 & 20,5 \\
\hline Подяка & & 2,70 & $+0,9$ & $115-119$ & 39,5 & 22,5 \\
\hline $\mathrm{HIP}_{05}$ & - & 0,18 & - & - & - & - \\
\hline
\end{tabular}

Урожайність у конкурсному сортовипробуванні у 1992-1994 рр. становила 1,49 т/га, що на 0,31 т/га більше, ніж у стандарту та вихідної форми сорту Білосніжка. У виробничих умовах в ДП ДГ „Елітне” Харківської області у 1993-1996 рр. урожайність досягнула 2,35-2,50 т/га, у 2005 році 3,20 т/га, потенційна урожайність сорту становить 3,5-3,7 т/га. Сорт ранньостиглий з тривалістю вегетаційного періоду 90-100 діб, має підвищену стійкість до посухи, стійкий до вилягання, обсипання насіння, збудників хвороб і шкідників. Вміст білка в насінні - 39,5 \%, олії - 21,5 \%. Сорт занесений до Держреєстру з 1998 року по Лісостепу та Степу України. У 2004 р. він був лідером в Україні за площами посіву, у 2005 р. сорт був на другому місці, у 2006 - на четвертому [2].

Зернокормовий сорт Скеля створений в результаті дії на насіння сорту Еванс розчину нітрозоетилсечовини в концентрації 0,012 \%. Він відрізняється від вихідної форми за біологічними (тривалість вегетації) та морфологічними ознаками. Урожайність у конкурсному сортовипробуванні у 20002002 рр. складала 2,26 т/га, що на 0,47 т/га більше, ніж у стандарту Київська 27. У виробничих умовах в 2005 році отримано по 3,00 т/га зерна, потенційна урожайність сорту 3,50-4,00 т/га. Сорт середньостиглий, тривалість веге- 
таційного періоду 110-115 діб. Він відрізняється високим прикріпленням нижнього бобу (16-18 см), стійкий до посухи, вилягання, обсипання насіння, збудників хвороб і шкідників. Вміст білка в насінні $-39,5 \%$, олії $23,5 \%$. Сорт придатний для виробництва зерна, а також кормів, як у чистих, так і у сумісних посівах. Сорт Скеля занесений до Держреєстру з 2006 року по Лісостепу та Степу.

Сорт сої зернового напряму використання Величава створений методом добору із сорту мутантного походження Скеля. На відміну від вихідної форми він має квітки білого кольору, менш високорослий та формує меншу вегетативну масу. У конкурсному сортовипробуванні у 2002-2004 pp. сорт перевищив стандарт Київська 27 по урожайності на 0,45 т/га при рівні урожайності 2,68 т/га. У виробництві в ДП ДГ „Елітне” в 2005 році урожайність становила 2,90 т/га. Сорт належить до середньоскоростиглої групи з тривалістю вегетаційного періоду 110-115 діб, має високе прикріплення нижнього бобу (15-17 см). Він характеризується високою стійкістю до посухи, вилягання, обсипання насіння, збудників хвороб і шкідників. Має високий вміст в насінні білка $-40,5 \%$ та олії - 22,0 \%. Сорт занесено до Держреєстру з 2007 року по Поліській та Степовій зонах.

Зерновий сорт сої Подяка одержаний методом хімічного мутагенезу шляхом обробки 0,025 \% розчином нітрозометилсечовини насіння селекційного зразка 76-249. Урожайність у конкурсному сортовипробуванні у 2006-2008 рр. складала 2,7 т/га, що на 0,9 т/га більше, ніж у стандарту Київська 27. Сорт середньостиглий (тривалість вегетаційного періоду 115-119 діб), посухостійкий, стійкий до вилягання, обсипання насіння, збудників хвороб і шкідників. Вміст білка в насінні 39-40\%, олії 22-23\%. Сорт занесено до Держреєстру з 2012 року по Лісостепу та Степу України.

Висновки. Показано ефективність використання хімічних мутагенів в селекції сої. В результаті застосування хімічних мутагенів (діетилсульфату, нітрометилсечовини та нітрозоетилсечовини) створено нові високопродуктивні, різноманітні за ідентифікаційними ознаками сорти сої, придатні для вирощування у різних природно-кліматичних зонах. До сортів зернового напряму використання відносяться Романтика, Величава, Подяка. Сорти сої Харківська зернокормова та Скеля придатні як для виробництва зерна, так і для кормовиробництва.

Створено різноманітний за господарськими та біологічними ознаками вихідний матеріал мутантного походження, який використовується в селекційному процесі.

\section{Список використаних джерел}

1. Соя / [под. ред. Ю. П. Мякушко, В. Ф. Баранова]. - М.: Колос, 1984. $328 \mathrm{c}$.

2. Бабич А. О. Селекція і виробництво сої в Україні / А. О. Бабич, А. А. Бабич-Побережна. - Вінниця, 2008. - 215 с. 
3. Соя (генетика, селекция, семеноводство) / [А. К. Лещенко, В. И. Сичкарь, В. Г. Михайлов, В. Ф. Марьюшкин].- К.: Наукова думка, 1987.- 256 с.

4. Генетика сои / [А. К. Лещенко, В. Г. Михайлов, В. И. Сичкарь, Л. Г. Щелко, Н. В. Кудрякова] // Генетика культурных растений: зернобобовые, овощные, бахчевые.- Л.: ВО “Агропромиздат”, Ленинградское отд., 1990.- С. 111-134.

5. Частная селекция полевых культур / [под. ред. проф. Ю. Б. Коновалова]. М.: Агропромиздат, 1990. - С. 269-284.

6. Методика Державного сортовипробування сільськогосподарських культур. - К.: , 2001.- 68 c.

Проанализирована эффективность применения химических мутагенов в селекции сои. Созданы высокопродуктивные мутантные сорта сои зернового и зернокормового направлений использования: Харьковская зернокормовая, Романтика, Скеля, Величава, Подяка.

The effectiveness of application of chemical mutagenes in soybean breeding was studied. The high-productive mutant soybean varieties of grain and grain-feeding utilization directions were created, such as: Kharkovskaya zernokormovaya, Romantika, Skelya, Velychava, Podyaka. 